\title{
Ethanol extracts of Cinnamomum kanehirai Hayata leaves induce apoptosis in human hepatoma cell through caspase- 3 cascade
}

This article was published in the following Dove Press journal:

OncoTargets and Therapy

31 December 2014

Number of times this article has been viewed

\author{
Yu-Kuo Liu' \\ Kuan-Hsing Chen ${ }^{2}$ \\ Yann-Lii Leu ${ }^{3,4}$ \\ Tzong-Der Way ${ }^{5}$ \\ Ling-Wei Wang ${ }^{6,7}$ \\ Yu-Jen Chen $8,9, *$ \\ Yu-Ming Liu ${ }^{6-8, *}$
}

'Department of Chemical and Material Engineering, Chang Gung University, Kwei-Shan, Tao-Yuan, Taiwan; ${ }^{2}$ Kidney

Research Center, Chang Gung Memoria Hospital, School of Medicine, ${ }^{3}$ Graduate Institute of Natural Products, College of Medicine, ${ }^{4}$ Chinese Herbal Medicine Research Team, Healthy Aging Research Center, Chang Gung University, Taoyuan, Taiwan; ${ }^{5}$ Department of Biological Science and Technology, China Medical University, Taichung, Taiwan; ${ }^{6}$ Division of Radiation Oncology, Department of Oncology, Taipei Veterans General Hospital, Taipei, Taiwan;

${ }^{7}$ National Yang-Ming University, Taipei,

Taiwan; ${ }^{8} \mathrm{School}$ of Medicine, Institute of Traditional Medicine, National Yang Ming University, Taipei, Taiwan; ' ${ }^{9}$ epartment of Radiation Oncology, Mackay Memorial Hospital, Taipei, Taiwan

*These authors contributed equally to this work

Correspondence: Yu-Ming Liu

Division of Radiation Oncology,

Department of Oncology, Taipei

Veterans General Hospital, 20I, Sec 2,

Shih-Pai Road, Taipei 11217, Taiwan

Tel +886 228757270 ext 3 I 8

Fax +886228749425

Email ymliug@gmail.com

Yu-Jen Chen

Department of Radiation Oncology,

Mackay Memorial Hospital, Taipei,

Taiwan

Tel +886225433535

Fax +886228096180

Email chenmdphd@gmail.com

\begin{abstract}
Inducing apoptosis to susceptible cells is the major mechanism of most cytotoxic anticancer drugs in current use. Cinnamomum kanehirai Hayata (Lauraceae), a unique and native tree of Taiwan, is the major host for the medicinal fungus Antrodia cinnamomea which exhibits anti-cancer activity. Because of the scarcity of A. cinnamomea, C. kanehirai Hayata instead, is used as fork medicine in liver cancer. Here we observed the C. kanehirai Hayata ethanol extract could inhibit the cellular viability of both HepG2 and HA22T/VGH human hepatoma cell lines in a dose- and time-dependent manner. We found the mode of cell death was apoptosis according to cell morphological changes by Liu's stain, oligonucleosomal DNA fragmentation by gel electrophoresis, externalization of phosphotidyl serine by detecting Annexin $\mathrm{V}$ and hypoploid population by cell cycle analysis. Our results showed that the extracts caused cleavage of caspase- 3 and increased enzyme activity of caspase- 8 and caspase- 9 . Caspase 3 inhibitor partially reversed the viability inhibition by the extract. Furthermore, the up-regulation of Bax and down-regulation of Bcl-2 were also noted by the extract treatment. In conclusion, C. kanehirai Hayata ethanol extract induced intrinsic pathway of apoptosis through caspase-3 cascade in human hepatoma HA22T/VGH and HepG2 cells, which might shed new light on hepatoma therapy.
\end{abstract}

Keywords: Antrodia cinnamomea, hepatoma, apoptosis, anticancer

\section{Introduction}

Cinnamomum kanehirai Hayata (Lauraceae) is a unique and native tree of Taiwan. It grows in the mountains at an altitude of about 450-2,000 m around the broad-leaved forests in Taiwan. In traditional Chinese medicine, it is claimed to be beneficial to clear the lungs, dispel apathy, and calm nervous depression. Since it contains a rich amount of camphor oil, it is used as an essential oil in aromatherapy or topical application for health promotion and some dermatological diseases. Essential oil of C. kanehirai Hayata has been reported to have antimicrobial activities. ${ }^{1}$

C. kanehirai Hayata is the major host for medicinal fungus Antrodia cinnamomea, ${ }^{2}$ which exhibits potential anticancer and hepato-protective properties. ${ }^{3-7}$ People hew this tree to harvest or cultivate its infected fungus, $A$. cinnamomea, for treatment of diseases in folk medicine. Growing evidences show that extracts, fermented products, or compounds isolated from $A$. cinnamomea possess growth inhibitory activity against various types of cancers. ${ }^{8,9}$ Other than its infected fungus, $A$. cinnamomea, little is known about the bioactivity of this plant per se.

In this study, we firstly proved the viability inhibitory effect of different C. kanehirai Hayata extracts (CKHE), including water extract (CKHE-W) and 
ethanol extract (CHKE-E), on human hepatoma HA22T/ VGH and HepG2 cells. Furthermore, the mode of cell death and putative mechanism of action were also assessed.

\section{Materials and methods}

\section{Chemicals}

Fetal calf serum, Dulbecco's Modified Eagle's Medium (DMEM), penicillin G, streptomycin, and amphotericin B was bought from GIBCO BRL (Gaithersburg, MD, USA). Dimethyl sulfoxide (DMSO), ribonuclease (RNase), and propidium iodide (PI) were acquired from Sigma-Aldrich Co. (St Louis, MO, USA). Caspase-3, -8, -9, Bax, and Bcl-2 antibodies were obtained from Santa Cruz Biotechnology Inc. (Santa Cruz, CA, USA). Anti-Bax antiserum was acquired from BD Pharmingen (San Diego, CA, USA). Caspase-3 inhibitor, Z-DEVD-FMK, was purchased from R\&D Systems, Inc. (Minneapolis, MN, USA).

\section{Raw material and preparation of $C$. kanehirai Hayata leaf extract}

The C. kanehirai Hayata was obtained from National Dongshih Forest District Office, Forestry Bureau, Council of Agriculture, Executive Yuan, Taiwan. Powdered leaves were soaked in water (CKHE-W) and ethanol (CKHE-E) $(1: 4 \mathrm{w} / \mathrm{w})$ at $70^{\circ} \mathrm{C}$ for 3 days. After filtered with filter paper (Advantec No 1; Toyo Roshi Kaisha Ltd, Tokyo, Japan), the residue was extracted under same conditions. In total, three extractions were taken. The filtrates collected from three separate extractions were further evaporated to dryness under vacuum. The CKHE was stored at $-30^{\circ} \mathrm{C}$. Sesamin, 5,4'-dihydroxy-7-methoxyflavone, 2-methylpropyl benzoate, methyl-(21R)-pheophoride a, and pheophorbide $\mathrm{b}$ methyl ester were isolated through repeated chromatography of CKHE. For all experiments, the stock was dissolved in water at $\mathrm{pH} 7.2$ and was filtered by a $0.22 \mu \mathrm{m}$ sterile filter. The final concentrations of the tested extracts were prepared by diluting the stock with DMSO. Control cultures received $0.1 \%$ DMSO, which had been proven not toxic to cultured cells.

\section{Cell culture and cell viability assay}

Human hepatoma cell lines, HA22T/VGH ${ }^{10}$ and HepG2 (HB8065; American Type Culture Collection [ATCC], Manassas, VA, USA), were maintained in monolayer cultured in DMEM containing $584 \mathrm{mg} / \mathrm{mL}$ L-glutamine and $10 \%$ fetal bovine serum, $10 \mathrm{U} / \mathrm{mL}$ of penicillin, $10 \mathrm{mg} / \mathrm{mL}$ of streptomycin, and $0.25 \mathrm{mg} / \mathrm{mL}$ of amphotericin $\mathrm{B}$, at $37^{\circ} \mathrm{C}, 5 \% \mathrm{CO}_{2}$, and $90 \%$ relative humidity. Cells were seeded at a density of $5 \times 10^{4}$ cells per well onto a 96-well plate (Falcon ${ }^{\mathrm{TM}}$; BD, Franklin Lakes, NJ, USA) 24 hours prior to drug treatment. CKHE-W and CKHE-E were added to medium, at various times and concentrations. Cells viability was examined using a modified MTT (3-(4,5-dimethylthiazol-2-yl)-2,5diphenyltetrazolium bromide) assay. ${ }^{11}$ All tests and analyses were performed in triplicate.

\section{Evaluation of cell morphology}

For observation of morphology, the cells were treated with $0.5 \mathrm{mg} / \mathrm{mL}$ CKHE-E for 48 hours, collected, and centrifuged on a slide using a Cytospin 2 centrifuge (Shandon Inc., Pittsburgh, PA, USA). The slides were dried, and cells were fixed with $4 \%$ paraformaldehyde in phosphate-buffered saline (PBS) (pH 7.4) and mounted in VECTASHIELD ${ }^{\circledR}$ mounting medium with $1.5 \mu \mathrm{g} / \mathrm{mL}$ 4',6-diamidino-2-phenylindole (Vector Laboratories, Inc., Burlingame, CA, USA). The cells were stained by method of Liu's stain and observed by light microscope (Olympus, Tokyo, Japan) at a magnification of 400 or 1,000 . Photograph was taken with a digital camera (Olympus, Tokyo, Japan).

\section{Evaluation of DNA fragmentation}

Fragmented DNA was analyzed by electrophoresis as illustrated by Herrmann et al. ${ }^{12}$ Firstly, cells were collected by centrifugation, and the pellets were lysed in DNA lysis buffer (20 mM Tris, $0.2 \%$ Triton X-100, 10 mM EDTA, pH 8.0) for 15 minutes, and then the lysate was centrifuged at $13,000 \times g$, for 10 minutes, all under $4^{\circ} \mathrm{C}$. The fragmented DNA containing supernatant was collected and incubated at $50^{\circ} \mathrm{C}$ overnight with proteinase $\mathrm{K}(0.1 \mathrm{mg} / \mathrm{mL})$ for protein digestion, then treated with RNase $(50 \mu \mathrm{g} / \mathrm{mL})$ at $37^{\circ} \mathrm{C}$ for 30 minutes. The DNA was extracted with phenol/chloroform/ isoamyl alcohol $(25: 24: 1, \mathrm{v} / \mathrm{v} / \mathrm{v})$ and precipitated in $50 \%$ isopropanol with $1 \mu \mathrm{L}$ of glycogen $(20 \mu \mathrm{g} / \mathrm{mL})$ at $-20^{\circ} \mathrm{C}$ overnight. After centrifugation at $15,000 \times g$ for 30 minutes to settle down, semi-dried, the DNA was dissolved in $10 \mu \mathrm{L}$ Tris acetate EDTA (TAE) (pH 8.0) buffer, then with electrophoresis in a $2.0 \%$ agarose gel containing ethidium bromide $(1 \mu \mathrm{g} / \mathrm{mL})$ in TAE buffer. The gel was resolved with ultraviolet light.

\section{Measurements of apoptosis by flow cytometry}

After incubation with various concentrations of CKHE-E for 24 and 48 hours, cells were harvested, washed with PBS, and resuspended $\left(1 \times 10^{6}\right.$ cells $\left./ \mathrm{mL}\right)$ in Annexin-V-FLUOS labeling solution (Annexin-V-FLUOS staining kit; Hoffman-La 
Roche Ltd, Basel, Switzerland) for 15 minutes in the dark at $37^{\circ} \mathrm{C}$. The fluorescence was analyzed by a FACSCalibur flow cytometer (Epics Altra; Beckman Coulter Taiwan Inc., Taipei, Taiwan). Green fluorescence was measured to indicate the proportion of the undergoing apoptosis (FITC [fluorescein isothiocyanate]-conjugated Annexin-V), and red fluorescence (PI) was measured to indicate the proportion of the cells with necrosis.

\section{Cell cycle assay}

Flow cytometric analysis was performed to determine cell cycle change after treatment with various concentrations of CKHE-E for 24 and 48 hours. The cells were washed and resuspended in PBS $\left(1 \times 10^{6}\right.$ cells $\left./ \mathrm{mL}\right)$ before being fixed in $75 \%$ ethanol. PI solution $(50 \mu \mathrm{g} / \mathrm{mL}$ PI, $0.1 \%$ sodium citrate, $0.1 \%$ Nonidet P-40) was used to stain total cellular DNA at room temperature for 30 minutes before analysis by a FACSCalibur ${ }^{\mathrm{TM}}$ flow cytometer.

\section{Evaluation of caspase- 8 and caspase- 9 activity}

HepG2 cells were treated with vehicle $(0.1 \%$ DMSO) and $0.25 \mathrm{mg} / \mathrm{mL}$ CKHE-E, for $6,12,24$, and 48 hours. The activity levels of caspase- 8 and -9 of cell lysate were determined by caspase- 8 and -9 Colorimetric Assay Kit (BioVision Research Products, Palo Alto, CA, USA), respectively. The detailed protocol is as described in the manufacturer's protocol. In brief, cells were plated at a density of $1 \times 10^{6}$ in $10 \mathrm{~cm}$ dishes 24 hours before the induction of apoptosis. After CKHE-E treatment, cells $\left(1 \times 10^{6}\right)$ were lysed on ice for 10 minutes and centrifuged $(10,000 \times g, 1$ minute). The supernatant was incubated for 1 to 2 hours at $37^{\circ} \mathrm{C}$ with benzyloxycarbonyl-Ile-Glu-Thr-Asp-p-nitroanilide or acetylLeu-Glu-His-Asp-p-nitroanilide color substrates (200 $\mu \mathrm{M})$. The samples were analyzed by spectrophotometer $(400 \mathrm{~nm})$. Assays were done in triplicate.

\section{Western blotting assay}

After treatment with various concentrations of CKHE-E for 12 and 24 hours, cells were washed with PBS and lysed with extraction buffer (1\% sodium dodecyl sulfate [SDS], $10 \mathrm{mM}$ sodium orthovanadate, $10 \mathrm{mM}$ Tris, $\mathrm{pH}$ $=7.4)$. Cellular debris was cleared by centrifugation $(1,300$ rpm, 10 minutes, $4^{\circ} \mathrm{C}$ ), and the protein concentration in the supernatant was determined by a protein assay kit (Micro-BCA protein assay; Pierce, Rockford, IL, USA). An equal amount of protein was subjected to SDSpolyacrylamide gel electrophoresis and transferred onto a PVDF (polyacrylidenedifluoride) membrane (Bio-Rad Laboratories Inc., Hercules, CA, USA). The membranes were probed with caspase-3, Bax, and Bcl-2 human antibodies (Santa Cruz Biotechnology, Inc.). The proteins were visualized by use of an horseradish peroxidase (HRP) detection system (Pierce).

\section{Statistical assay}

Data were represented as means \pm standard errors. Variance analysis was used for statistical comparisons of the results. ${ }^{13}$ Significant differences $(P<0.05)$ between the means of control and CKHE-treated cells were analyzed by Dunnett's test.

\section{Results}

\section{Inhibition of cellular viability by CKHE}

To evaluate the antitumor effect of CKHE to human hepatoma cells, various concentrations of CKHE were used to treat HA22T/VGH and HepG2 cells for 12, 24, and 48 hours, respectively, and examined for cellular viability by MTT assay. Our results showed that CKHE-E had greater viability-inhibitory activity compared with $\mathrm{CKHE}-\mathrm{W}$ in HA22T/VGH and HepG2 cells $(P<0.05)$ (Figure 1A and B). Both time- and dose-dependent inhibition in viability were also noted. CKHE-E had lower 50\% inhibitory concentration $\left(\mathrm{IC}_{50}\right)$ of cellular viability inhibition compared with $\mathrm{CKHE}-\mathrm{W}$ in these hepatoma cells (Table 1). Because CKHE-E had greater viability-inhibitory activity, we chose CKHE-E for the future experiments. These results showed that CKHE-E exhibited high potency in inhibiting cell proliferation in hepatoma cells.

\section{Effects of CKHE-E on inducing apoptosis in hepatoma cells}

To determine whether CKHE-E induced apoptosis in hepatoma cells, the phenotypic characteristics of CKHEE-treated hepatoma cells were evaluated by microscopic inspection of overall morphology. Figure 2 shows morphological changes of both HA22T/VGH and HepG2 human hepatoma cells by treatment with $0.5 \mathrm{mg} / \mathrm{mL}$ CKHE-E for 48 hours. The microscope results showed the typical morphological characteristics of apoptosis, such as cell shrinkage and apoptotic body formation, were observed. Neither cell swelling nor cell lysis as characteristic feature of necrosis was noted.

We further elucidated whether CKHE-E also induced DNA fragmentation in hepatoma cells. Our agarose gel electrophoresis results showed formation of DNA fragments in 
A

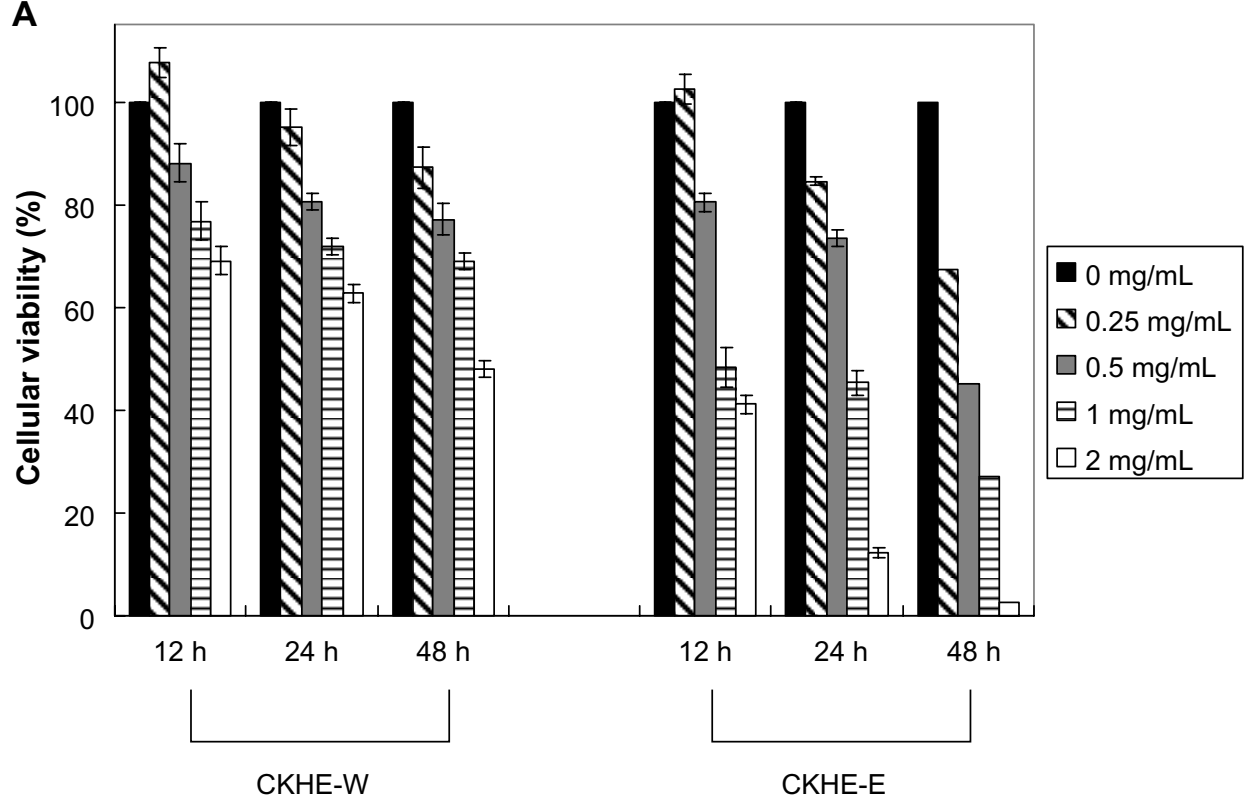

B

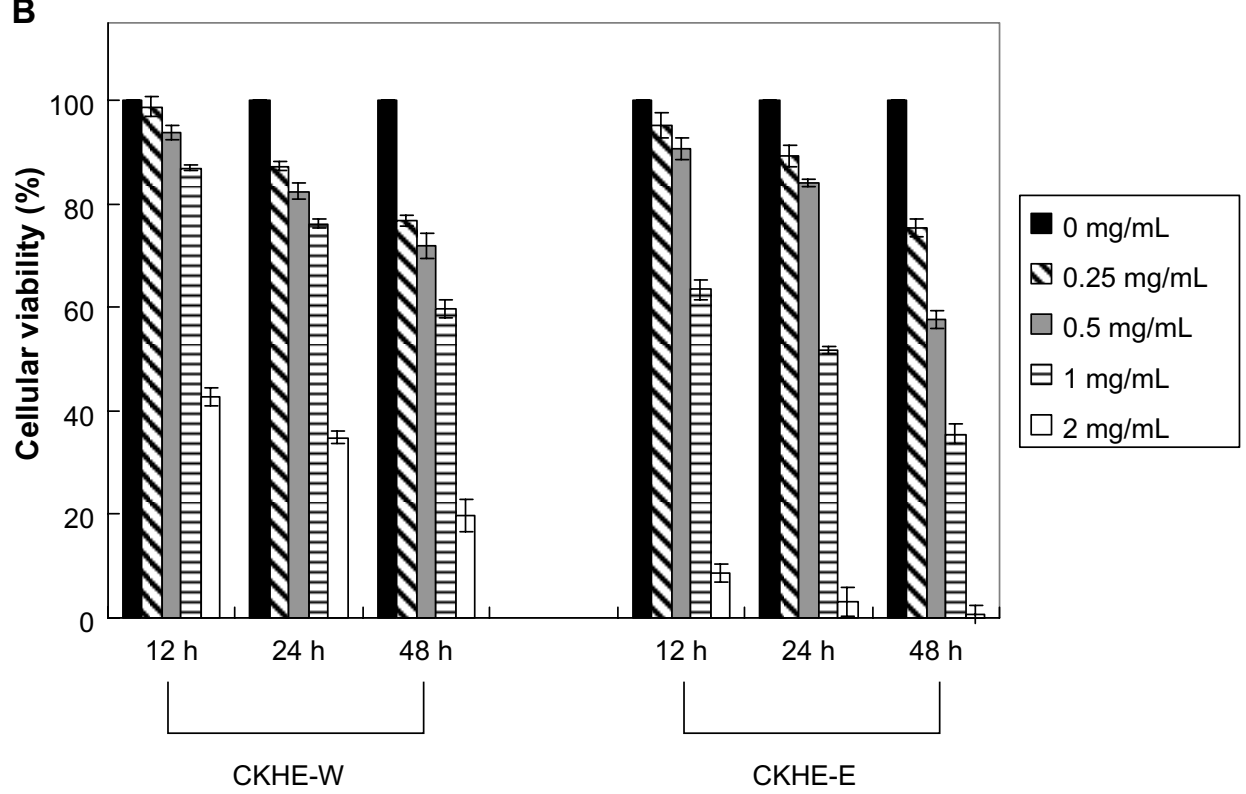

Figure I The anti-proliferation activities of different fractions from Cinnamomum kanehirai Hayata leaves against human hepatoma cells. HA22T/VGH cells (A) and HepG2 cells (B) were treated with CKHE-W or CKHE-E $(0.25-2.00 \mathrm{mg} / \mathrm{mL})$ for 12, 24, and 48 hours, respectively. The cell viability was then determined using MTT assay. Notes: This experiment was repeated three times. The data represents the mean \pm SD.

Abbreviations: CKHE-E, ethanol Cinnamomum kanehirai Hayata extract; CKHE-W, water Cinnamomum kanehirai Hayata extract; MTT, 3-(4,5-dimethylthiazol-2-yl)-2,5diphenyltetrazolium bromide; SD, standard deviation; h, hours.

both HA22T/VGH and HepG2 cells after CKHE-E treatment for 24 hours (Figure 3A).

To further investigate CKHE-E-induced hepatoma cell apoptosis, flow cytometric analysis was performed. HA22T/VGH and HepG2 cells were treated with 0.5 and $1.0 \mathrm{mg} / \mathrm{mL}$ of CKHE-E for 24 and 48 hours, and percentages of apoptosis were determined by the Annexin-V/PI staining and flow cytometric method (Figure $3 \mathrm{~B}$ ). The results showed both CKHE-E-treated cells had increase apoptotic cell percentage compared with untreated cells in a time- and dose- dependent manner.

\section{Effects of CKHE-E on cell cycle distribution}

To determine whether CKHE-E altered cell cycle progression, we performed flow cytometry by using PI staining. HA22T/VGH and HepG2 cells were treated with different concentrations of CKHE-E, and the cell-cycle distribution 
Table I Summary of the $\mathrm{IC}_{50}$ values for inhibiting HA22T/VGH and HepG2 human hepatoma cell viability by CKHE-E

\begin{tabular}{llll}
\hline Cell line & $\begin{array}{l}\text { Time, } \\
\text { hours }\end{array}$ & $\begin{array}{l}\text { CKHE-W, } \\
\mathbf{m g} / \mathbf{m L}\end{array}$ & $\begin{array}{l}\text { CKHE-E, } \\
\mathbf{m g} / \mathbf{m L}\end{array}$ \\
\hline HA22T/VGH & 12 & $3.79 \pm 0.54$ & $0.93 \pm 0.14$ \\
& 24 & $2.58 \pm 0.06$ & $0.87 \pm 0.05$ \\
& 48 & $1.85 \pm 0.06$ & $0.25 \pm 0.06$ \\
HepG2 & 12 & $1.92 \pm 0.03$ & $1.03 \pm 0.01$ \\
& 24 & $1.66 \pm 0.02$ & $0.86 \pm 0.03$ \\
& 48 & $1.5 \pm 0.01$ & $0.76 \pm 0.04$ \\
\hline
\end{tabular}

Notes: Data were calculated as $\mathrm{IC}_{50}$. Experiments were performed in triplicate in three independent experiments.

Abbreviations: CKHE-E, ethanol Cinnamomum kanehirai Hayata extract; CKHE-W, water Cinnamomum kanehirai Hayata extract; $\mathrm{IC}_{50}, 50 \%$ inhibitory concentration.

was determined at 24 and 48 hours after treatment. Compared with the untreated control cells, the results indicated that CKHE-E could increase percentage of sub- $\mathrm{G}_{1}$ cells in a timeand dose-dependent manner, respectively (Figure 4).

\section{Effects of CKHE-E on caspase activation}

Caspase activation plays an important role in the initiation and success of apoptosis. To understand the molecular effectors pathway of CKHE-E-induced apoptosis, we studied whether caspases play a role as downstream effectors in CKHE-Emediated apoptosis. Our results found that cleavage patterns of caspase-3 (active caspase-3 [17 kDa]) were observed in HA22T/VGH and HepG2 cells in a time-dependent manner (Figure 5A). Figure 5B shows CKHE-E caused an increase in caspase- 8 and -9 proteolytic activities in $\mathrm{HepG} 2$ cell. After
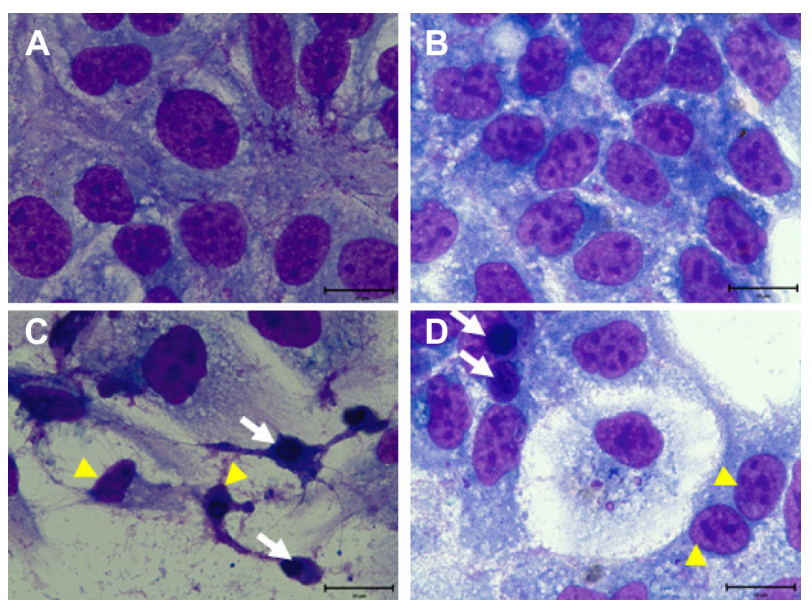

Figure 2 CKHE-E induced cell morphological change. Liu's stain morphology of HA22T/VGH and HepG2 human hepatoma cells ( $\mathbf{A}$ and $\mathbf{B}$ ), and both cells treated with $0.5 \mathrm{mg} / \mathrm{mL}$ for 48 hours (C and $\mathbf{D}$, respectively).

Notes: DAPI stain, original magnification $\times 1,000$; the triangle markers represent cell shrinkage; white arrow markers represent apoptotic body formation; scale bar, $20 \mu \mathrm{m}$.

Abbreviations: CKHE-E, ethanol Cinnamomum kanehirai Hayata extract; DAPI, 4',6-diamidino-2-phenylindole. treated with CKHE-E $(0.25 \mathrm{mg} / \mathrm{mL})$ for $6,12,24$, and 48 hours, the caspase activities were increasing up to 1.7-, 2.6-, 3.3-, and 2.6-fold in caspase-8, and 1.3-, 2.0-, 2.4-, and 2.1fold in caspase- 9 , compared with control group, respectively. These results demonstrated that activation of both caspase- 8 and -9 were noted from 6 hours after CKHE-E treatment and up to maximum at 24 hours and decreased thereafter. These results also demonstrated that both caspase- 8 and -9 activations might precede caspase- 3 activation in CKHE-induced death signaling.

\section{Effect of caspase-3 inhibitors on CKHE-E cell viability inhibition}

To further establish the role of caspase-3 in CKHE-E-induced apoptosis in hepatoma cells, a pharmacological inhibitor approach was employed. Specific caspase inhibitors were added selectively into CKHE-E-treated cells and followed by MTT assays. After HA22T/VGH and HepG cells were co-incubated with the cell-permeable caspase- 3 inhibitors $(50 \mu \mathrm{M})$ and CKHE-E for 48 hours, the caspase-3 inhibitor partially reversed the cell viability inhibition of CKHE-E $(P<0.05)$ (Figure 5C).

\section{Effect of CKHE-E on the expression of Bcl-2 family in HepG2 cells}

As demonstrated in Figure 5A, the expression of Bax was upregulated and, by contrast, the expression of Bcl-2 was downregulated by CKHE-E in a dose-dependent manner in HepG2 cells.

\section{Profile of constituents in CKHE-E}

To analyze the involved compositions of CKHE-E, liquid chromatography-mass spectrometry was performed. Five major compounds identified in CKHE-E were sesamin, 5,4'dihydroxy-7-methoxyflavone, 2-methylpropyl benzoate, meth$\mathrm{yl}-(21 R)$-pheophoride $\mathrm{a}$, and pheophorbide $\mathrm{b}$ methyl ester.

\section{Cellular viability inhibition effect of sesamin, methyl (2IR) pheophorbide a, and pheophorbide $b$ methyl ester in HA22T/VGH and HepG2 cells}

To evaluate the antitumor effect of sesamin, methyl (21R) pheophorbide $\mathrm{a}$, and pheophorbide $\mathrm{b}$ methyl ester against HA22T/VGH and HepG2 cells, the cells were treated with various concentrations of sesamin, methyl (21R) pheophorbide a, and pheophorbide b methyl ester (Figure 6) for 48 hours and examined for cell viability by MTT assay. Among these compounds, methyl (21R) pheophorbide a 


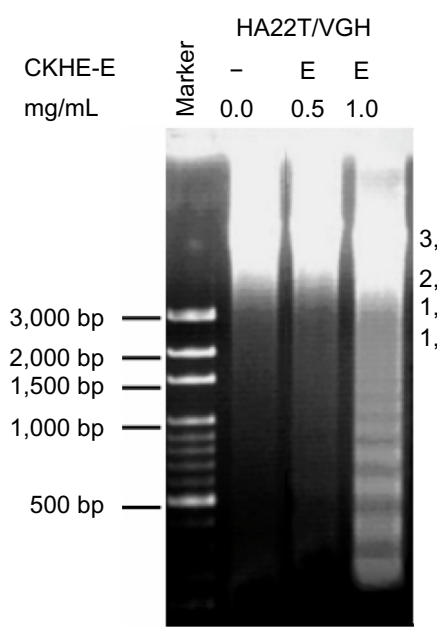

HA22T/VGH

$\mathrm{mg} / \mathrm{mL}$

0.0
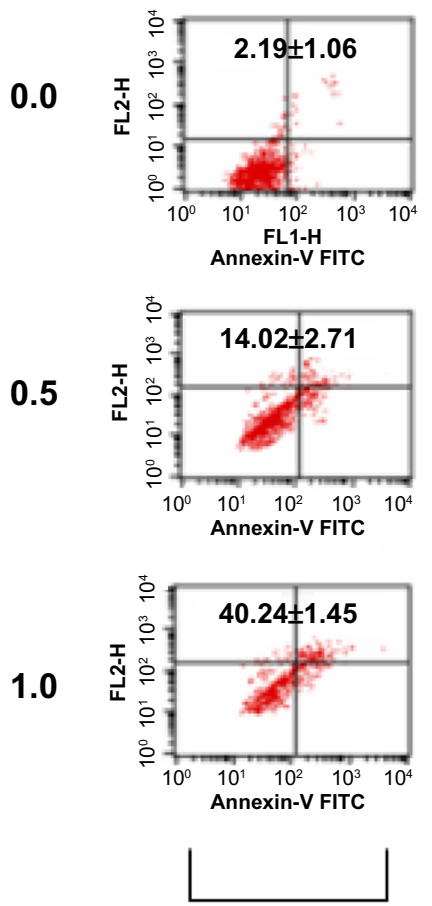

$24 \mathrm{~h}$
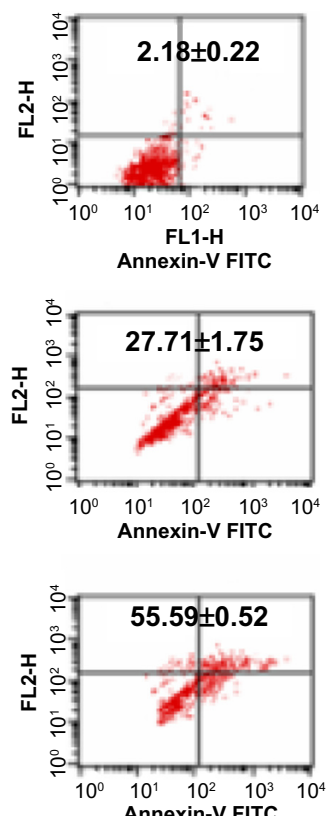

in-V FITC

$48 \mathrm{~h}$

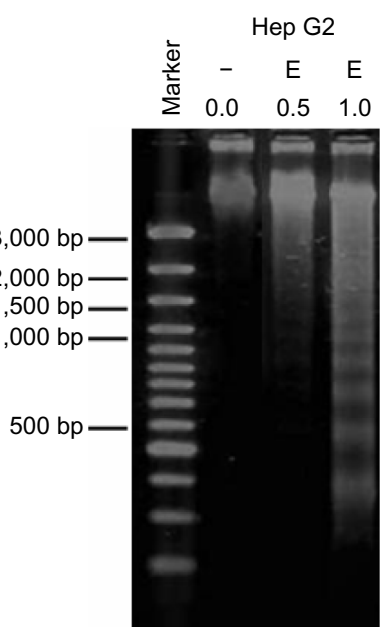

Hep G2
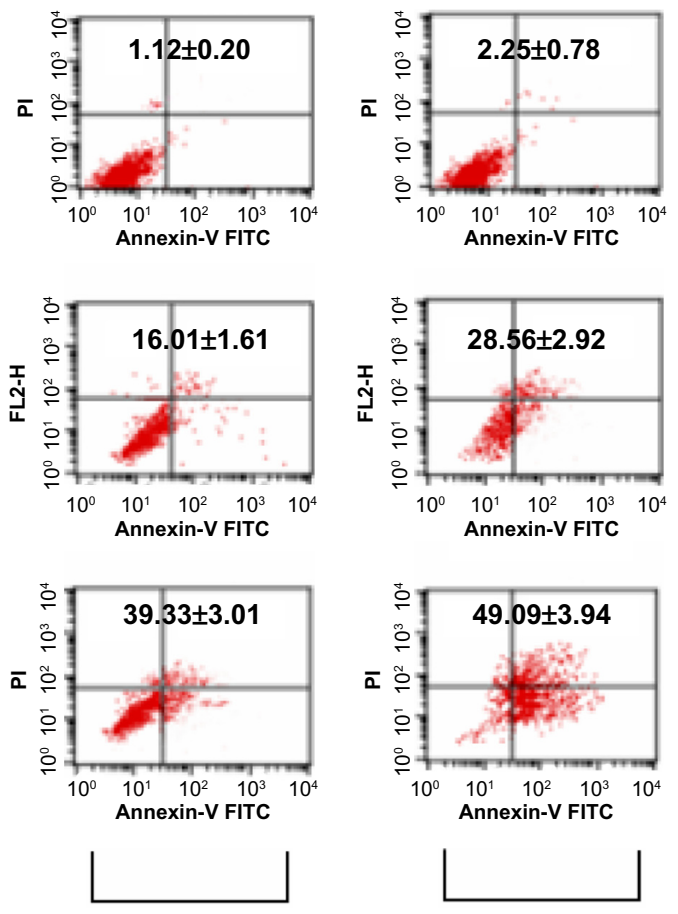

$24 \mathrm{~h}$

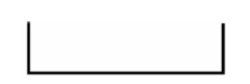

$48 \mathrm{~h}$

Figure 3 CKHE-E induced apoptosis in human hepatoma cells. (A) HA22T/VGH cells and HepG2 cells were treated with 0.5 or $1.0 \mathrm{mg} / \mathrm{mL}$ of CKHE-E for 24 hours, and examined by DNA fragmentation assay. (B) HA22T/VGH cells and HepG2 cells were treated with 0.5 or $1.0 \mathrm{mg} / \mathrm{mL}$ of CKHE-E for 24 and 48 hours, respectively. Notes: Cell apoptosis percentages were determined by flow cytometry with Annexin-V/PI staining. The experiments were repeated three times.

Abbreviations: CKHE-E, ethanol Cinnamomum kanehirai Hayata extract; PI, propidium iodide; h, hours.

exhibited the most efficient inhibitory effects on both cancer cells. These results showed that the inhibitory effect of methyl (21R) pheophorbide a was more remarkable in both cancer cells than sesamin and pheophorbide b methyl ester.

\section{Discussion}

In this study, CKHE-E was used to investigate its cytotoxicity on hepatoma cells. From MTT assay, cancer cell viability was decreased with the increasing CKHE-E dose and exposure time. The PI and Annexin-V staining results showed that the cell apoptosis had happened and the cell viability inhibition was increased with CKHE-E exposure time. The further observation of DNA fragmentation confirmed apoptosis.

From an ecological view, because $A$. cinnamomea is very rare and difficult to plant, extraction of the leaves was a feasible way to obtain a great quantity of high potential 


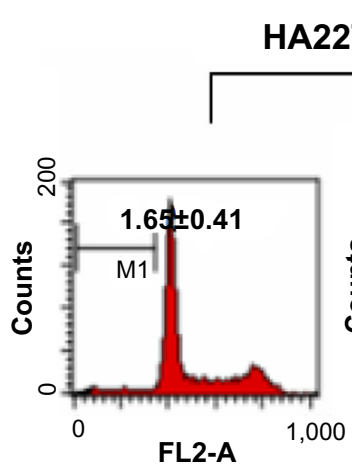

HA22T/VGH
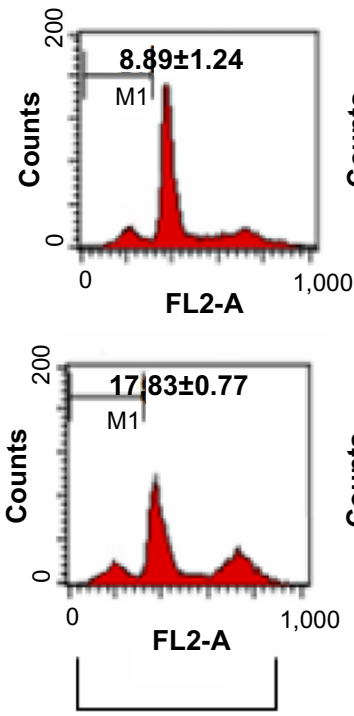

$24 \mathrm{~h}$
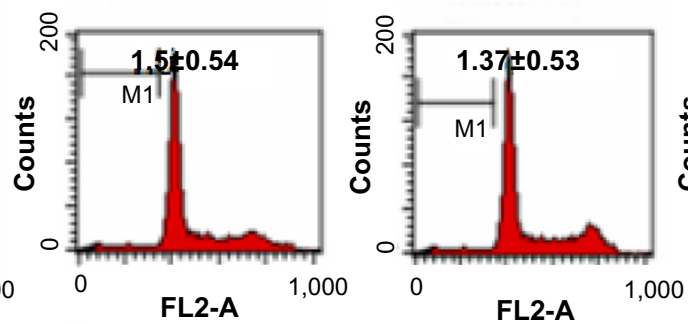

Hep G2
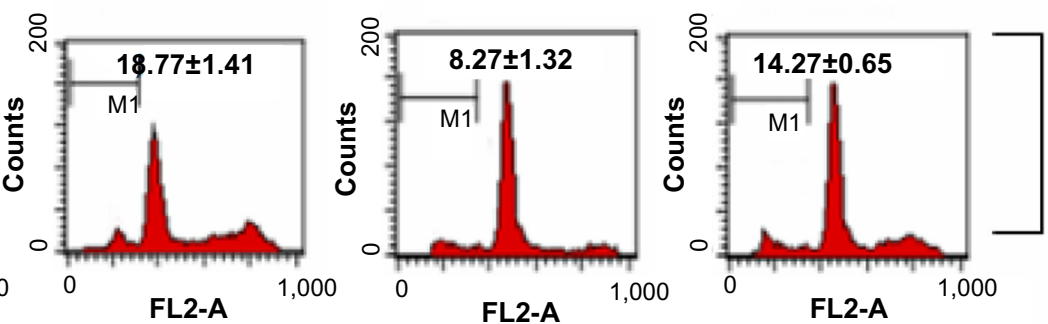

0.5

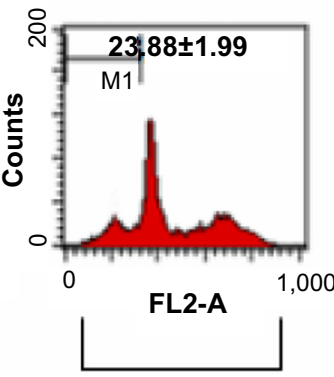

$48 \mathrm{~h}$

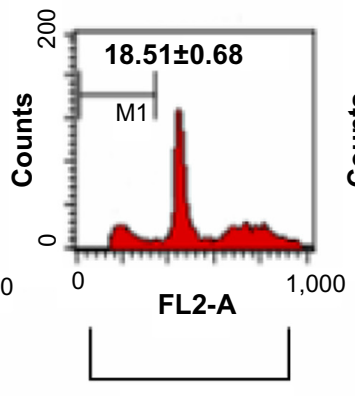

$24 \mathrm{~h}$

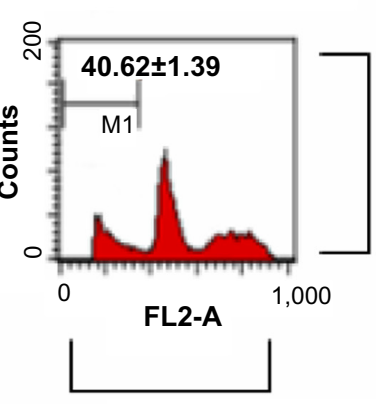

$48 \mathrm{~h}$

$\mathrm{mg} / \mathrm{mL}$

0.0

Figure 4 Effect of CKHE-E on cell cycle progression in human hepatoma cells. HA22T/VGH and HepG2 cells were treated with 0.5 and I.0 mg/mL CKHE-E for 24 and 48 hours, respectively, and analyzed for PI-stained DNA content by flow cytometry.

Notes: The indicated percentages are the mean of three independent experiments, each in triplicate. The sub-GI phase cells increased with time.

Abbreviations: CKHE-E, ethanol Cinnamomum kanehirai Hayata extract; PI, propidium iodide; h, hours.

therapeutic agent that had the advantage on rapid production. Besides, it may avoid C. kanehirai Hayata (one of the endangered trees) to become extinct in the world. Therefore, the CKHE-E could be a good chemotherapeutic agent for primary or adjuvant treatment of hepatoma.

In the present study, HA22T/VGH and HepG2 had similar $\mathrm{IC}_{50}$ of cytotoxic effect (Table 1) and percentage of apoptosis induced by CKHE-E (Figure 4). It was known that HepG2 and HA22T/VGH cells are different in functional p53, as wt p53 and p53-null, respectively; thus, we supposed that wt p53 does not play an important role in CKHE-E-induced apoptosis in hepatoma cells. The p53 tumor suppressor is a multifunctional protein that exerts a variety of different effects and plays a central role in the regulation of the normal cell cycle. Overexpression of the $\mathrm{p} 53$ protein inhibits cell growth and is associated with $\mathrm{G} 0$ / G1 checkpoint and induces apoptosis. ${ }^{14}$ However, our results showed similar cytotoxicity by induction of apoptosis in both cells, indicating that wt p53 upregulated by CKHE-E may not be an essential factor to induce apoptosis. Therefore, CKHE-E inhibited hepatoma cell viability by inducing apoptosis both in a p53-dependent and p53-independent pathway.

Caspase-3 is a well-known downstream effector caspase of caspase cascade which is activated in the apoptotic cell both by extrinsic (death ligand) and intrinsic (mitochondrial) pathways. ${ }^{15,16}$ As the results show in Figure 5A, CKHE-Einduced activation of caspase-3 was observed after 12- and 24-hour treatment in HepG2 cells and after 24-hour treatment in HA22T/VGH cells. Caspase-3 inhibitor partially blocked the growth inhibitory activity of CKHE-E, indicating a caspase-3-dependent effect (Figure 5C). Because of the increase in caspase- 8 and -9 activity by CKHE-E treatment (Figure 5B), it suggests that the induction of apoptosis by CKHE-E in HepG2 cells may involve both extrinsic and intrinsic pathways. The upregulation of Bax and downregulation of Bcl-2 by CKHE-E treatment further support the involvement of intrinsic apoptotic pathway. 
A

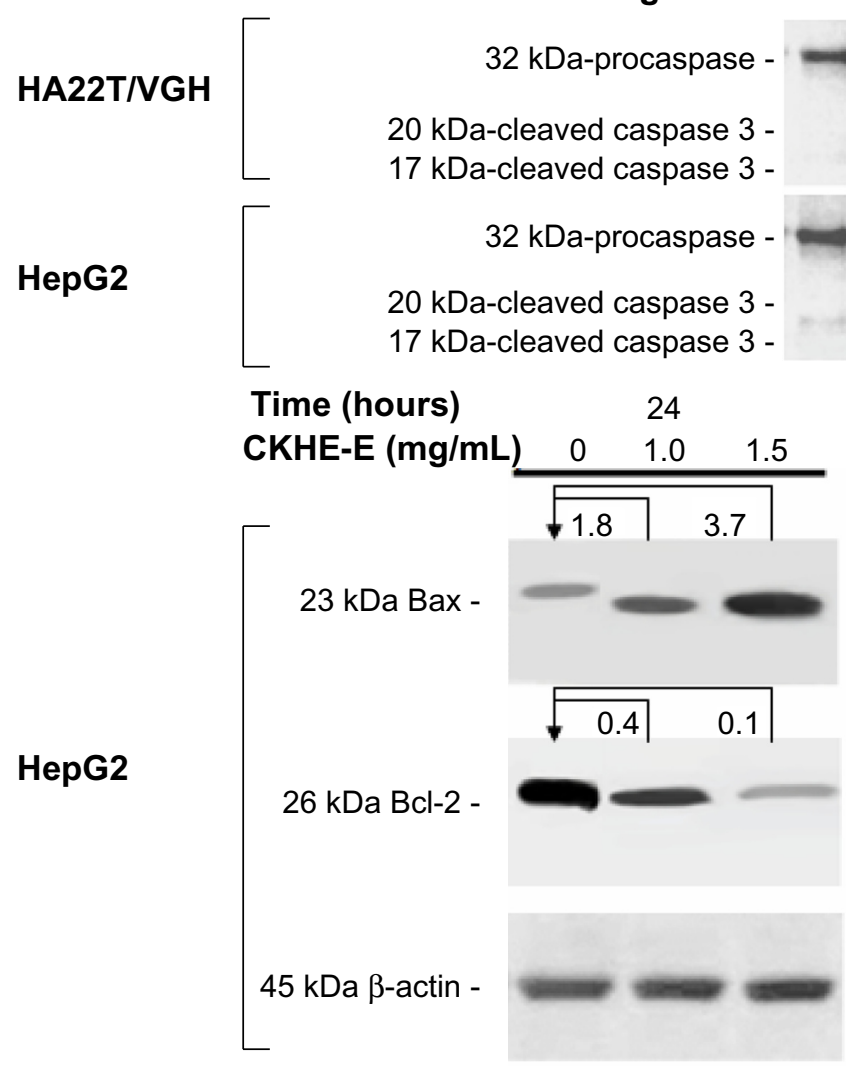

Time (hours) $12 \quad 24$

$-1.0-1.0$




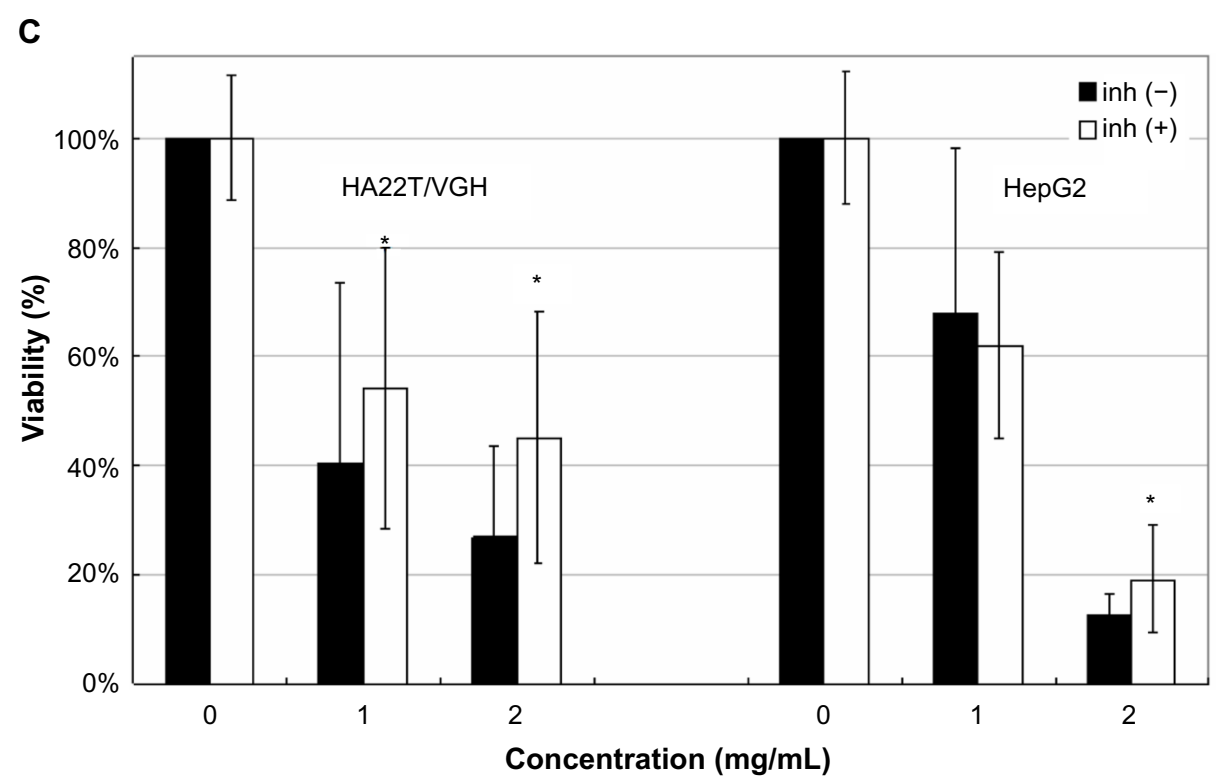

Figure 5 Effect of CKHE-E on human hepatoma cells intrinsic pathway of apoptosis. (A) HA22T/VGH and HepG2 cells treated with I.0 mg/mL CKHE-E for I 2 and 24 hours. Cells were then harvested and lysed for the detection of cleaved caspase-3, Bax, Bcl-2, and $\beta$-actin protein expression. (B) HepG2 cells treated with $0.25 \mathrm{mg} / \mathrm{mL}$ CKHE-E for 6, 12, 24, and 48 hours. Cells were then harvested and lysed for the detection of caspase-8 and -9 activity assay. (C) HA22T/VGH and HepG cells were co-incubated with the cell-permeable caspase-3 inhibitors $(50 \mu \mathrm{M})$ and CKHE-E (I and $2 \mathrm{mg} / \mathrm{mL})$ for 48 hours, respectively. The effect on cell growth was examined by MTT assay, and the percentage of cell proliferation was calculated by defining the absorption of cells with DMSO as $100 \%$.

Notes: This experiment was repeated three times. Bar represents the SEM. Values were significantly different from the control group. *P<0.05.

Abbreviations: CKHE-E, ethanol Cinnamomum kanehirai Hayata extract; DMSO, dimethyl sulfoxide; MTT, 3-(4,5-dimethylthiazol-2-yl)-2,5-diphenyltetrazolium bromide; SEM, standard error of the mean.

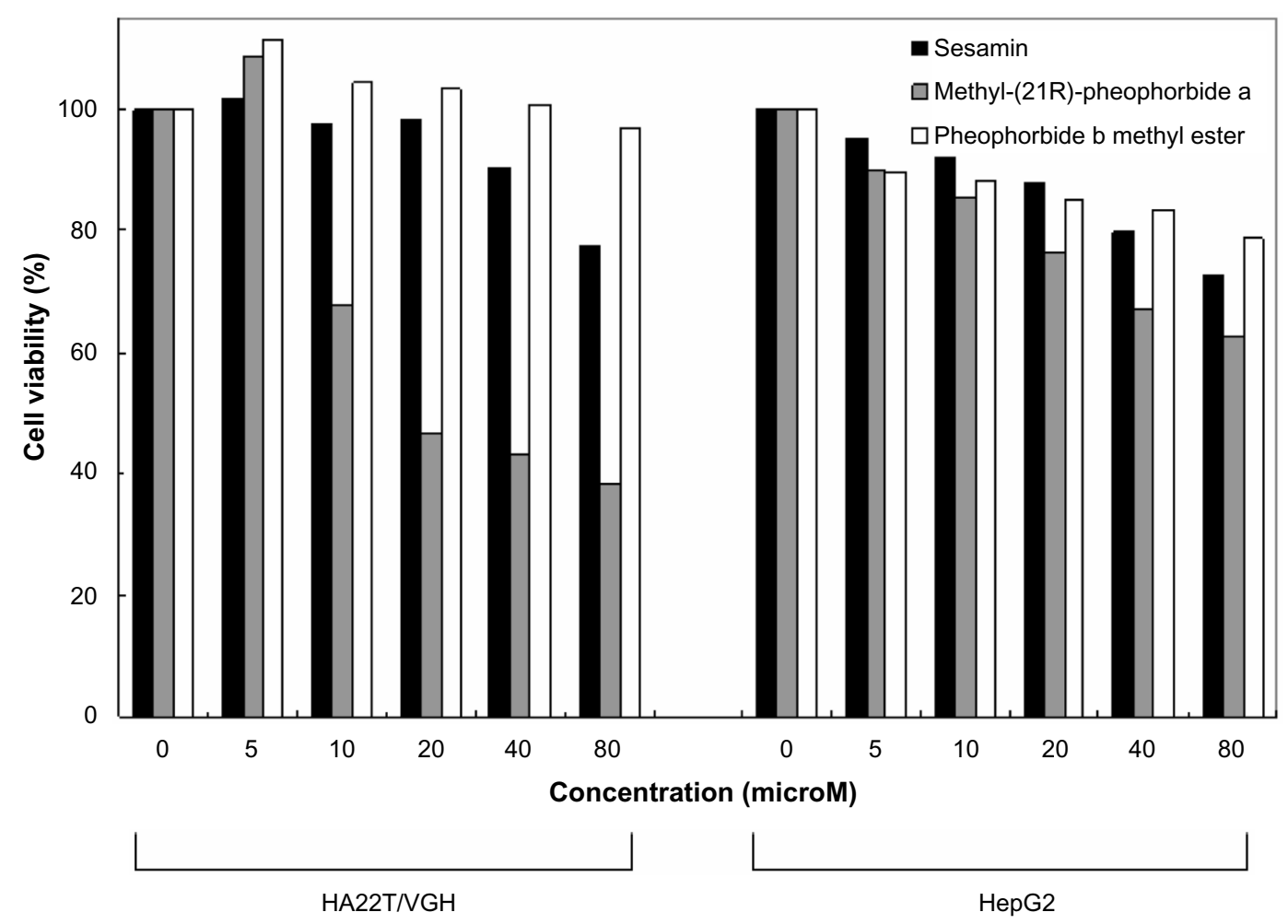

Figure 6 The anti-proliferation activities of sesamin, methyl (2IR) pheophorbide a, and pheophorbide b methyl ester on HA22T/VGH and HepG2 cells. Both HA22T/VGH and HepG2 cells were treated with various concentrations of sesamin, methyl (2IR) pheophorbide a, and pheophorbide b methyl ester at $37^{\circ} \mathrm{C}$ for 48 hours. The effect on cell growth was examined by MTT assay, and the percentage of cell proliferation was calculated by defining the absorption of control as $100 \%$.

Note: This experiment was repeated three times.

Abbreviation: MTT, 3-(4,5-dimethylthiazol-2-yl)-2,5-diphenyltetrazolium bromide. 
As an herbal extract, CKHE-E contains a variety of compounds that may act on different pathways of tumor cell growth. In this study, we found that CKHE-E contained five potential active compounds, including sesamin, 5,4'-dihydroxy-7methoxyflavone, 2-methylpropyl benzoate, methyl-(21R)pheophoride a, and pheophorbide b methyl. Sesamin, a major lignan in sesame oil, had been reported to have ability to inhibit HepG2 cell growth by inducing G2/M phase arrest and apoptosis. Deng et $\mathrm{al}^{17}$ reported that sesamin could suppress the interleukin-6-induced signal transducer and activator of transcription 3 signaling pathway in HepG2 cells, which lead to regulate the downstream genes, including p53, p21, cyclin proteins, and the Bcl-2 protein family. Though there is little documentation about methyl-(21R)-pheophorbide a and cancer, it has been reported that pheophorbide could not only induce cell cycle arrest at G2/M phase and inhibit the expressions of $\mathrm{G} 2 / \mathrm{M}$ phase cell cycle regulatory proteins in HepG2 human liver cancer cell line, but also induce apoptosis in Hep3B cells through sub-G1 cell cycle arrest. ${ }^{18,19}$ Cho et $\mathrm{al}^{20}$ reported that pheophorbide a could induce apoptosis in U87MG glioblastoma cells. Pheophorbide b methyl ester can induce apoptosis and DNA damage in both HL-60 and WEHI-3 leukemia cells. ${ }^{21}$ The compound 5,4'-dihydroxy-7methoxyflavone, known as Genkwanin, is an O-methylated flavone, a type of flavonoid reported to have anticancer activity against Huh 7, A 2058, B16, 231, MCF-7, COLO 205, A549, AGS, and HT-29 cells. ${ }^{22}$ However, which compounds may explain the anticancer activity of CKHE-E remains to be further characterized.

In conclusion, CKHE-E induced intrinsic pathway of apoptosis in human hepatoma HA22T/VGH and HepG2 cells. Development of novel anticancer agents against hepatoma from ethanol extract of $C$. kanehirai Hayata leaves is promising.

\section{Acknowledgments}

This research received a grant of V102C-159 from Taipei Veterans General Hospital and CMRPD2A0131, CMRPD2A0132 from Chang Gung University. We also thank Dr KL Lan, Mr HC Lin, and Ms SL Chou for technical assistance.

\section{Disclosure}

The authors report no conflicts of interest in this work.

\section{References}

1. Yeh RY, Shiu YL, Shei SC, et al. Evaluation of the antibacterial activity of leaf and twig extracts of stout camphor tree, Cinnamomum kanehirae, and the effects on immunity and disease resistance of white shrimp, Litopenaeus vannamei. Fish Shellfish Immunol. 2009;27:26-32.
2. Straub A, Benet-Buckholz J, Frode R, et al. Metabolites of orally active NO-independent pyrazolopyridine stimulators of soluble guanylate cyclase. Bioorg Med Chem. 2002;10:1711-1717.

3. Liu JJ, Huang TS, Hsu ML, et al. Antitumor effects of the partially purified polysaccharides from Antrodia camphorata and the mechanism of its action. Toxicol Appl Pharmacol. 2004;201:186-193.

4. Hsu YL, Kuo YC, Kuo PL, Ng LT, Kuo YH, Lin CC. Apoptotic effects of extract from Antrodia camphorata fruiting bodies in human hepatocellular carcinoma cell lines. Cancer Lett. 2005;221:77-89.

5. Hseu YC, Yang HL, Lai YC, Lin JG, Chen GW, Chang YH. Induction of apoptosis by Antrodia camphorata in human premyelocytic leukemia HL-60 cells. Nutr Cancer. 2004;48:189-197.

6. Hsu YL, Kuo PL, Cho CY, et al. Antrodia cinnamomea fruiting bodies extract suppresses the invasive potential of human liver cancer cell line PLC/PRF/5 through inhibition of nuclear factor kappa B pathway. Food Chem Toxicol. 2007;45:1249-1257.

7. Zisman A, Pantuck AJ, Chao DH, et al. Renal cell carcinoma with tumor thrombus: is cytoreductive nephrectomy for advanced disease associated with an increased complication rate? J Urol. 2002;168:962-967.

8. Chen YJ, Chou CJ, Chang TT. Compound MMH01 possesses toxicity against human leukemia and pancreatic cancer cells. Toxicol In Vitro. 2009;23:418-424

9. Liu YM, Liu YK, Lan KL, Lee YW, Tsai TH, Chen YJ. Medicinal fungus Antrodia cinnamomea inhibits growth and cancer stem cell characteristics of hepatocellular carcinoma. Evid Based Complement Alternat Med. 2013;2013:569737.

10. Lin YM, Hu CP, Chou CK, et al. [A new human hepatoma cell line: establishment and characterization]. Zhonghua Min Guo Wei Sheng Wu Ji Mian Yi Xue Za Zhi. 1982;15:193-201. Chinese.

11. Plumb JA, Milroy R, Kaye SB. Effects of the $\mathrm{pH}$ dependence of 3-(4,5-dimethylthiazol-2-yl)-2,5-diphenyl-tetrazolium bromideformazan absorption on chemosensitivity determined by a novel tetrazolium-based assay. Cancer Res. 1989;49:4435-4440.

12. Herrmann M, Lorenz HM, Voll R, Grunke M, Woith W, Kalden JR. A rapid and simple method for the isolation of apoptotic DNA fragments. Nucleic Acids Res. 1994;22:5506-5507.

13. El Bahi S, Caliot E, Bens M, et al. Lymphoepithelial interactions trigger specific regulation of gene expression in the $\mathrm{M}$ cell-containing follicle-associated epithelium of Peyer's patches. J Immunol. 2002;168:3713-3720.

14. Wieler S, Gagné JP, Vaziri H, Poirier GG, Benchimol S. Poly(ADP-ribose) polymerase-1 is a positive regulator of the $\mathrm{p} 53$-mediated $\mathrm{G} 1$ arrest response following ionizing radiation. $J$ Biol Chem. 2003;278:18914-18921.

15. Salvesen GS. Caspases: opening the boxes and interpreting the arrows. Cell Death Differ. 2002;9:3-5.

16. Ghavami S, Hashemi M, Ande SR. Apoptosis and cancer: mutations within caspase genes. J Med Genet. 2009;46:479-510.

17. Deng P, Wang C, Chen L, et al. Sesamin induces cell cycle arrest and apoptosis through the inhibition of signal transducer and activator of transcription 3 signalling in human hepatocellular carcinoma cell line HepG2. Biol Pharm Bull. 2013;36:1540-1548.

18. Tang PM, Chan JY, Zhang DM, et al. Pheophorbide a, an active component in Scutellaria barbata, reverses P-glycoprotein-mediated multidrug resistance on a human hepatoma cell line R-HepG2. Cancer Biol Ther. 2007;6:504-509.

19. Chan JY, Tang PM, Hon PM, et al. Pheophorbide a, a major antitumor component purified from Scutellaria barbata, induces apoptosis in human hepatocellular carcinoma cells. Planta Med. 2006;72:28-33.

20. Cho M, Park GM, Kim SN, Amna T, Lee S, WS. S. Glioblastoma-specific anticancer activity of pheophorbide a from the edible red seaweed Grateloupia elliptica. J Microbiol Biotechnol. 2014;24:346-353.

21. Chou ST, Chan HH, Peng HY, Liou MJ, TS W. Isolation of substances with antiproliferative and apoptosis-inducing activities against leukemia cells from the leaves of Zanthoxylum ailanthoides Sieb. and Zucc. Phytomedicine. 2011;18:344-348.

22. Li S, Chou G, Hseu Y, Yang H, Kwan H, Z. Y. Isolation of anticancer constituents from flos genkwa (Daphne genkwa Sieb.et Zucc.) through bioassay-guided procedures. Chem Cent J. 2013;7:159. 
OncoTargets and Therapy

\section{Publish your work in this journal}

OncoTargets and Therapy is an international, peer-reviewed, open access journal focusing on the pathological basis of all cancers, potential targets for therapy and treatment protocols employed to improve the management of cancer patients. The journal also focuses on the impact of management programs and new therapeutic agents and protocols on
Dovepress

patient perspectives such as quality of life, adherence and satisfaction. The manuscript management system is completely online and includes a very quick and fair peer-review system, which is all easy to use. Visit http://www.dovepress.com/testimonials.php to read real quotes from published authors.

\footnotetext{
Submit your manuscript here: http://www.dovepress.com/oncotargets-and-therapy-journal
} 